\title{
Overshot Flaking at the Arc Site, Genesee County, New York: Examining the Clovis-Gainey Connection
}

\author{
Metin I. Eren*,1, Stanley Vanderlaan ${ }^{2}$ and John D. Holland ${ }^{3}$ \\ ${ }^{I}$ Department of Anthropology, Southern Methodist University, Campus PO Box 750336, Dallas, Texas 75275-0336, \\ USA \\ ${ }^{2}$ Rochester Museum and Science Center, Rochester, New York, USA \\ ${ }^{3}$ Buffalo Museum of Science, Buffalo, New York, USA
}

\begin{abstract}
There are a number of purported distinctions between Clovis and Gainey technology. Prominent among these is the lack of overshot flaking in the production of Gainey bifaces. A recent survey of debitage from the Arc site in western New York state suggests that overshot flaking was indeed practiced by Paleoindians in the Lower Great Lakes, suggesting that Clovis and Gainey technology may be more similar than generally thought. It is concluded that a technological, and perhaps terminological, reexamination of the "Gainey concept" is in order.
\end{abstract}

Keywords: Arc Site NY, Paleoindians, Late pleistocene lithic technology, Overshot flaking, North American Great Lakes region.

\section{INTRODUCTION}

The term "Clovis" has been used to represent many concepts: a group of people, a culture, an adaptation, a technology, and a fluted projectile-point type [1]. Regarding the fluted point type, Clovis is now rarely seen as pancontinental phenomenon, geographically or temporally. Instead, numerous stylistic variations, seemingly based on or evolved from the Clovis fluted point, are recognized across North America [2]. The meaning and timing of these different "style zones" are currently under debate, having been attributed to factors such as cultural drift or adaptation to the environment [3,4].

If the Clovis fluted point type is limited only to certain parts of North America, is Clovis lithic technology also geographically and temporally constrained? This question is difficult to answer given the nebulous relationship between a stone tool's final form and the technology used to achieve that form. "Technology" is understood here as culturallyinfused ideals and strategies pertaining to the creation of objects. In some cases, the form of a stone tool may be attained with multiple technologies. For example, long and narrow prismatic blades can be produced from a bifacial precore and prepared platforms, or from an unprepared core and plain platforms. In other cases, the same technological concept can be used to produce significantly different forms. This latter instance is exemplified by isolated and projected platforms which can be used either for prismatic blade reduction or the removal of bifacial thinning flakes.

In the Lower Great Lakes (Fig. 1) colonizing Paleoindian sites are often referred to as to "Gainey" sites [5-8]. In addition to post-dating Clovis, Gainey Paleoindians also

*Address correspondence to this author at the Department of Anthropology, Southern Methodist University, Campus PO Box 750336, Dallas, Texas 75275-0336, USA; Tel: 214.768.4152: E-mail: meren@smu.edu supposedly manufactured their own distinctive fluted projectile-points. In regards to the technology for the creation of projectiles, Morrow and Morrow [9] suggest that a number of distinctions between Gainey and Clovis exist [10], Table 2.2b, [11], Table 4). However, Morrow and Morrow [9] rightly caution that their observations may be "skewed" since they were based upon finished and exhausted projectile points. Of the numerous purported technological distinctions between Clovis and Gainey bifaces (Table 1) that might be concealed by the analysis of finished and exhausted tools is the practice of "transverse flaking," otherwise known as overshot flaking. This is because overshot flaking is often applied during the early stages of bifacial reduction to remove square edges or stacks, or to quickly thin a biface. Subsequent resharpening and reduction can also hide overshot flake scars. Overshot flakes themselves may be left at quarry/workshop sites, of which there are few in the Lower Great Lakes, or be turned into tools, concealing any diagnostic trace. Overshot flaking is defined here following Bradley et al. [1] "as the flintknapping strategy where flakes travel from one margin across a face of a biface (or any other form) and remove part of the opposite margin. The other margin may be bifacially or unifacially flaked or may be natural. However, to be considered an overshot the removed portion must be a margin (lateral edges), not simply the other end (distal/proximal end) of a core or piece of raw material".

There have been occasional hints that overshot flaking was practiced by colonizing Paleoindians in the Great Lakes and Northeastern North America [12]. Prufer and Baby [13] describe some "convex-parallel-sided" Paleoindian projectile-points in Ohio as possessing the trait. Tankersley [14] mentions that there is evidence of overshot flaking at the Emanon Pond site. And of course it is possible for a flintknapping mistake to result in the odd overshot flake [15], like possibly at Paleo Crossing [16]. However, the exhausted and ephemeral nature of Paleoindian tools, the 


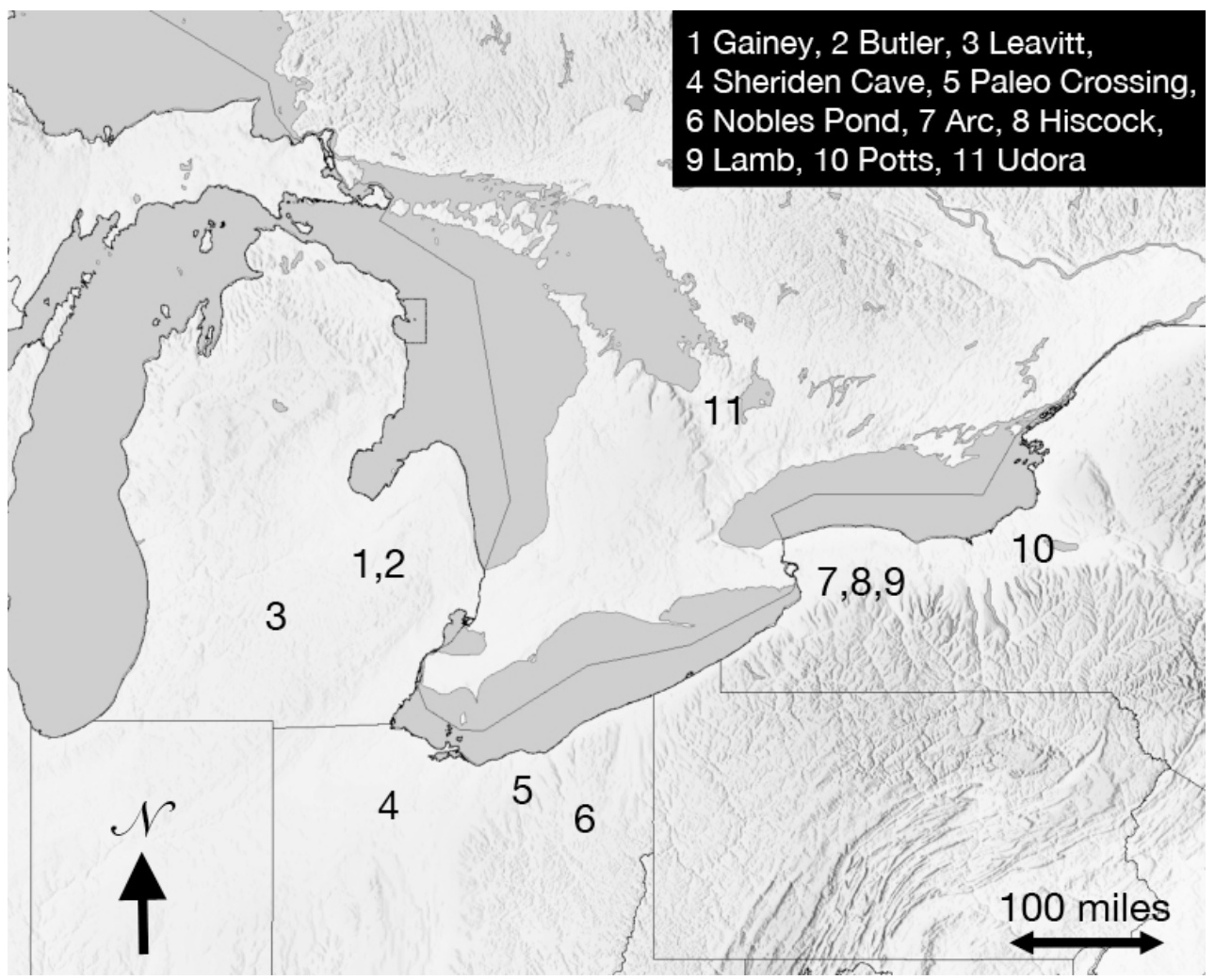

Fig. (1). The location of "Gainey" sites in the North American Lower Great Lakes region.

Table 1. Purported Distinctions Between Clovis and Gainey Technology and Fluted Point Forms (Reproduced from [10], Table 2.2b and [11], Table 4)

\begin{tabular}{|c|c|}
\hline Thicker average cross-section $(>7.0 \mathrm{~mm})$ & Relatively thin cross-section $(5-7 \mathrm{~mm})$ \\
\hline Excurvate edges & Slightly excurvate or parallel edges \\
\hline No "guide flutes" & "Guide flutes" to create an arris for final fluting \\
\hline Prepared fluting platforms isolated in center plane of biface & Platforms low to center plane \\
\hline Fluting done in middle stages of manufacture with direct percussion & Fluting done in late stages with indirect percussion \\
\hline Wider faces & Less wide faces \\
\hline Ground along lower lateral and basal edges & Ground along lower lateral and basal edges; distal also may be blunt or ground \\
\hline Thicker interflute measurement $(\approx 7.0 \mathrm{~mm})$ & Thinner interflute measurement $(\approx 5.0 \mathrm{~mm})$ \\
\hline Additional thinning after fluting & Only pressure flaking to finish point after fluting \\
\hline
\end{tabular}


Table 2. Basic Descriptive Traits and Measurements of the Twenty-Five Overshot Specimens, and the Three Plunging Specimens

\begin{tabular}{|c|c|c|c|c|c|c|c|c|c|}
\hline $\begin{array}{l}\text { Overshot } \\
\text { specimen }\end{array}$ & Figure & Type & Mass (g) & $\begin{array}{c}\text { Raw Mate- } \\
\text { rial }\end{array}$ & $\begin{array}{c}\text { Axial } \\
\text { Length } \\
(\mathbf{m m})\end{array}$ & $\begin{array}{l}\text { Medial } \\
\text { Width } \\
(\mathbf{m m})\end{array}$ & $\begin{array}{c}\text { Medial } \\
\text { Thickness } \\
(\mathbf{m m})\end{array}$ & $\begin{array}{l}\text { Platform } \\
\text { Width } \\
(\mathbf{m m})\end{array}$ & $\begin{array}{l}\text { Platform } \\
\text { Depth } \\
\text { (mm) }\end{array}$ \\
\hline 1 & 2 & Biface & 18.8 & Onondaga & 55.44 & 34.81 & 8.42 & -- & -- \\
\hline 2 & 3 & Biface & 16.1 & Onondaga & 42.27 & 36.86 & 6.92 & -- & -- \\
\hline 4 & 5 & Biface & 29.8 & Onondaga & 33.17 & 46.74 & 15.07 & -- & -- \\
\hline 5 & 6 & Biface & 14.9 & Onondaga & 28.38 & 29.44 & 12.79 & -- & -- \\
\hline 6 & 7 & Biface & 15.1 & Onondaga & 46.14 & 23.55 & 9.16 & -- & -- \\
\hline 8 & 9 & Flake & 21.0 & Onondaga & 53.09 & 39.10 & 8.99 & 5.12 & 3.16 \\
\hline 9 & 10 & Flake & 33.2 & Onondaga & 50.39 & 30.75 & 12.47 & 6.99 & 3.05 \\
\hline 10 & 11 & Flake & 24.3 & Onondaga & 54.55 & 33.99 & 14.45 & -- & -- \\
\hline 11 & 12 & Flake & 36.8 & Onondaga & 44.98 & 52.52 & 17.23 & -- & -- \\
\hline 12 & 13 & Flake & 27.9 & Onondaga & 63.58 & 26.36 & 9.76 & 4.19 & 2.47 \\
\hline 13 & 14 & Flake & 11.1 & Unidentified & 51.41 & 30.86 & 5.80 & -- & -- \\
\hline 18 & 19 & Flake & 6.6 & Onondaga & 37.26 & 28.41 & 5.39 & -- & -- \\
\hline 19 & 20 & Flake & 7.8 & Onondaga & 32.71 & 25.14 & 5.17 & -- & -- \\
\hline 20 & 21 & Flake & 5.9 & Onondaga & 28.13 & 24.84 & 6.15 & -- & -- \\
\hline 21 & 22 & Flake & 4.8 & Onondaga & 37.48 & 17.21 & 6.28 & 5.58 & 1.70 \\
\hline 22 & 23 & Flake & 11.9 & Onondaga & 40.31 & 21.83 & 11.45 & -- & -- \\
\hline 23 & 24 & Flake & 5.2 & Onondaga & 27.63 & 24.07 & 7.11 & -- & -- \\
\hline 24 & 25 & Flake & 6.9 & Onondaga & 26.73 & 29.78 & 7.11 & -- & -- \\
\hline 25 & 26 & Flake & 6.2 & Onondaga & 28.62 & 30.29 & 4.03 & -- & -- \\
\hline Plunging 1 & 27 & Biface & 41.9 & Onondaga & 50.88 & 44.96 & 14.90 & -- & -- \\
\hline Plunging 2 & 28 & Biface & 35.6 & Onondaga & 45.48 & 38.91 & 11.86 & -- & -- \\
\hline Plunging 3 & 29 & Core & 46.8 & Onondaga & 53.02 & 47.86 & 15.96 & -- & -- \\
\hline
\end{tabular}


lack of evidence involving early stage bifaces, and limited account in the literature leave in doubt the nature of overshot flaking in the Late Pleistocene Great Lakes. Was it used often and "intentionally" like Clovis technology, or does the occasional overshot flake simply represent a mistake or unintended result?

A recent survey of lithic debitage at the Arc site suggests that, indeed, overshot flaking was practiced by colonizing Paleoindians in the Great Lakes. The Arc site is located in Genesee County, New York, approximately five kilometers north of the Onondaga Escarpment [17-20]. It is perhaps not surprising then that a majority of the lithic artifacts are made from local Onondaga chert. Tankersley et al. [19] interpret the site as a "workshop," which is appropriate given the large quantity of flaked stone at all stages of manufacture. Arc is unique in this sense among Great Lakes Paleoindian sites, which generally exhibit resharpened and exhausted tools from kill or food processing sites (e.g. Hiscock, Lamb) or habitation sites far from raw material sources (e.g. Paleo Crossing, Nobles Pond).

Radiocarbon dates "bracket" the Paleoindian occupation at the Arc site. Tankersley [20, 21] and Tankersley et al. [19] report that "a wood sample from the base of alluvium" of nearby Whitney Creek demonstrates that the waters from glacial Lake Tonawanda had drained from the Arc site by $11,700 \pm 110$ B.P. Two radiocarbon dates $(10,360 \pm 400$ B.P. and 10,375 \pm 110 B.P.) were also obtained on wood and peat samples from "a possible forest floor" at the base of the strata overlying the Paleoindian occupation. Thus, the $\mathrm{Pa}$ leoindian occupation falls between the oldest radiocarbon date and the weighted averaged of the two younger radiocarbon dates $(10,370 \pm 108$ B.P.).

\section{EVIDENCE OF OVERSHOT FLAKING}

The following descriptions and accompanying figures present an illustrative, ad hoc sample $(n=25)$ of overshot flaking at the Arc site. (M.I.E. was conducting his $\mathrm{PhD}$ research on another part of the Arc assemblage, and discovered the overshots while briefly perusing the debitage). This report is by no means intended to be a quantitative assessment or analysis, but basic measurements are included for each specimen (Table 2). Unfortunately, none of the authors presently have the opportunity to undertake a systematic exami- nation of the entire Arc site debitage collection, which is massive. We hope this report encourages other researchers to conduct further technological studies upon the collection.

Before presenting the specimen descriptions below, we would like to make one important distinction. Overshot flakes or flake scars interpreted as intentional and positive outcomes are called "overshot specimens." However, technologically speaking, overshot flakes or flake scars may also represent unintended and negative outcomes, such as when an early stage basal thinning flake plunges, splitting a biface in half. We call these negative examples "plunging specimens." By presenting three plunging specimens below, we hope to elucidate the distinction between margin removal and end removal that Bradley et al. [1] make in their definition of overshot flaking. We acknowledge that it is impossible to "prove" prehistoric intention in regards to an overshot flake, but we remain optimistic that documented patterns in the archaeological record, when assessed with proper understanding of middle-range analogies [22], can reveal behavioral reality.

\section{THE DESCRIPTIONS}

Overshot Specimen \#1, Biface (MDA 17-4 C-186), Fig. (2). This biface is snapped, so only the tip and mid-section are present. On one face (Fig. 2b) there are three adjacent parallel-oblique overshot scars, reminiscent of biface \#149 from the Fenn Cache [23], indicating the highest level of knapping skill and control. The alternate face exhibits large flake scars (Fig. 2d), but no overshot scars. The snapped cross-section displays some crystallization (Fig. 2d), leading us to wonder whether the biface broke during heat-treatment.

Overshot Specimen \#2, Biface (MDA 17-4 C-616), Fig. (3). This thin biface is snapped, only showing the tip and mid-section. One face displays a large overshot scar (Fig. 3b) that would have considerably thinned the biface from its previous state. Additionally, the alternate edge is square in shape, and the probable target of removal by the overshot, which was partially successful (Fig. 3a). Unfortunately for the prehistoric knapper, the toolstone contained a natural cleavage bed (Fig. 3d), which likely lead the biface to snap, resulting in its discard.

Overshot Specimen \#3, Biface (MDA 17-4 C-849), Fig. (4). This early stage biface is unbroken, and based on the

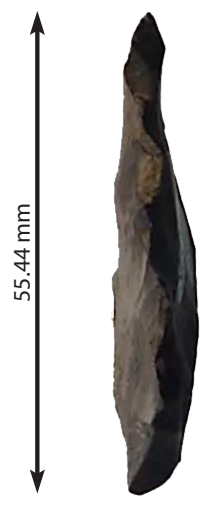

a

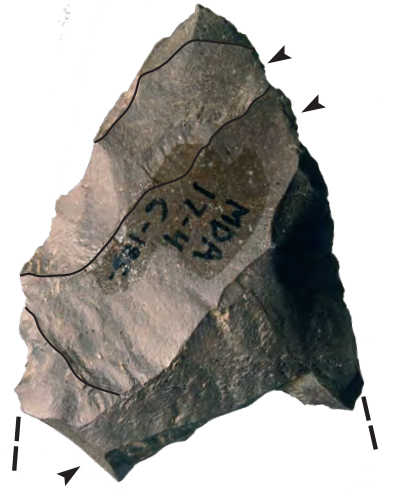

b

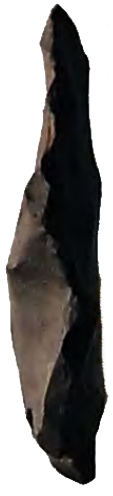

C

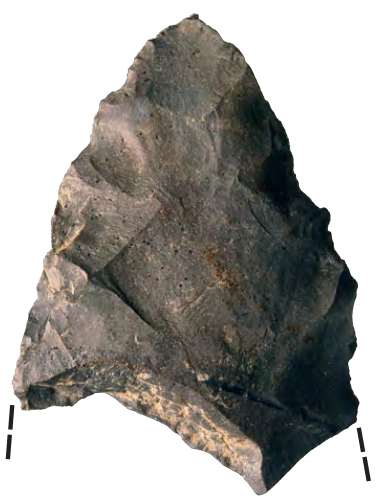

d

Fig. (2). Overshot Specimen \#1, Biface. 


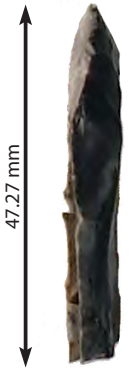

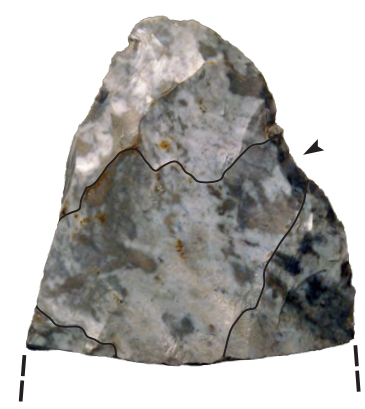

b

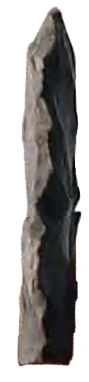

C

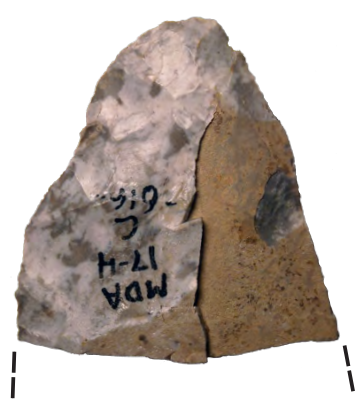

d

Fig. (3). Overshot Specimen \#2, Biface.

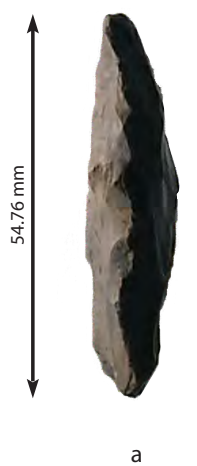

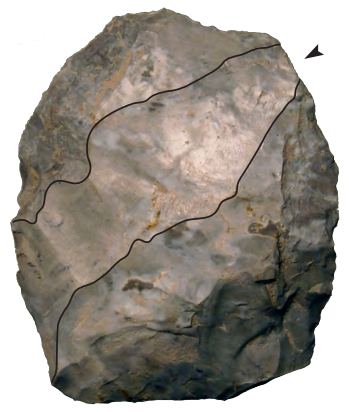

b

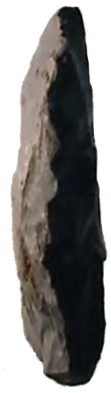

C

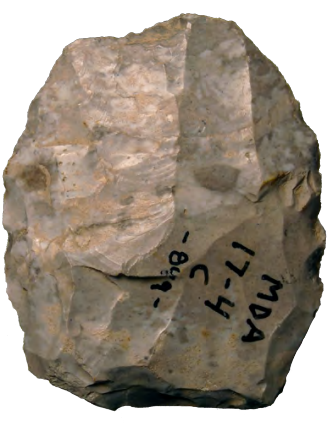

d

Fig. (4). Overshot Specimen \#3, Biface.

presence of a remnant platform, appears to have been fashioned on a large flake. One face shows parallel-oblique flaking, with one of the flake scars clearly indicating an overshot (Fig. 4b). Other flake scars on this face may be overshots, but are masked by resharpening and/or platform preparation scars. The alternate face displays thinning flake scars parallel to the long axis of the biface (Fig. 4d). Pot-lidding and sections of crystallization pepper the biface, again indicating a heat-treatment mishap.

Overshot Specimen \#4, Biface (B 1994), Fig. (5). The base of this early stage snapped biface exhibits an overshot scar on one face (Fig. 5b), knapped from a naturally occurring projected and isolated plain platform (Fig. 5c). The alternate face once again shows basal thinning flake scars (Fig. 5d). The biface apparently broke from a natural inclusion (Fig. 5d).

Overshot Specimen \#5, Biface (C 1999), Fig. (6). This bifacial mid-section exhibits an overshot on one face that appears to be an attempt to mitigate a deep concavity (Fig. 6b). The distal breakage is due to a basal thinning flake that plunged (Fig. 6d), while the proximal break appeared to be due to an incipient fracture.

Overshot Specimen \#6, Biface (MDA 17-4 B-8 346), Fig. (7). This is an ambitious attempt at a biface on a difficult tabular and angular nodule. The nodule may have proven too difficult though, and the biface was abandoned early. Nevertheless, an overshot scar (Fig. 7b) on one face was successful at both thinning the biface as well as partially removing a square edge (Fig. 7a).

Overshot Specimen \#7, Flake (B 1994), Fig. (8). This overshot flake removed the square edge of a tabular nodule. Along the flaking axis is a prominent dorsal ridge. The platform is heavily ground, with a small dorsal flake scar on each side of it, representing platform isolation. Examination of the ventral flake surface shows that the flake nearly stepped, but then continued to the square margin of the nodule.

Overshot Specimen \#8, Flake (MDA 17-4 B-185), Fig. (9). This overshot flake was struck to remove a square edge.
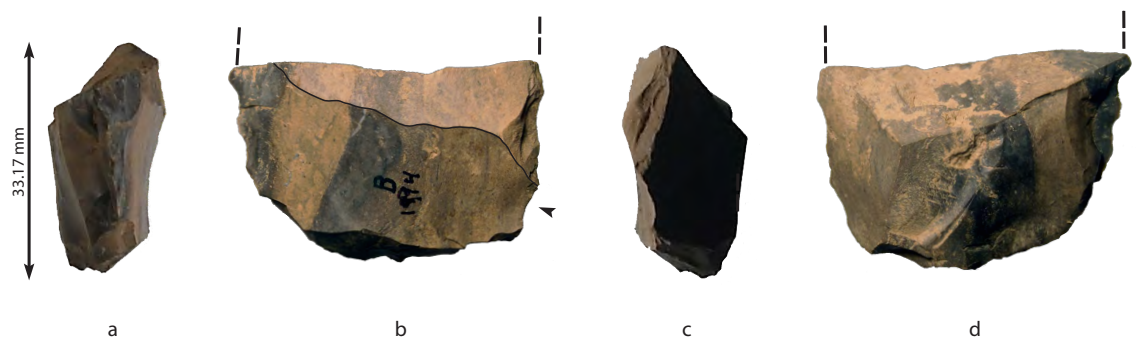

Fig. (5). Overshot Specimen \#4, Biface. 


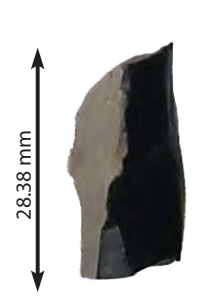

a

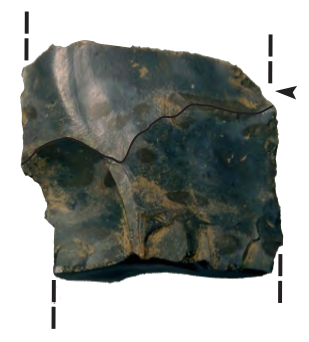

b

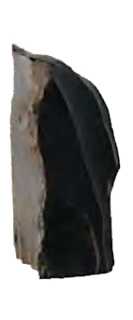

C

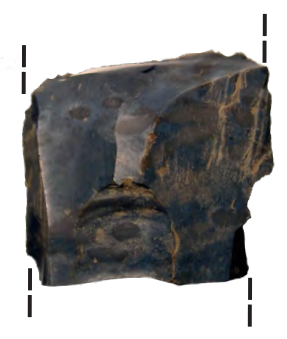

d

Fig. (6). Overshot Specimen \#5, Biface.

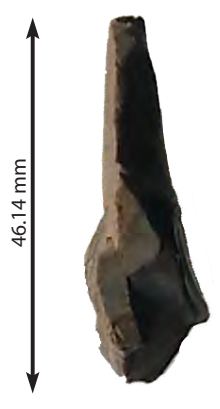

a

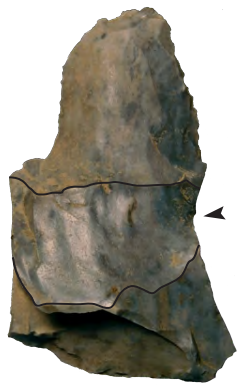

b

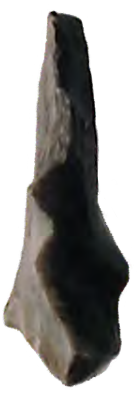

C

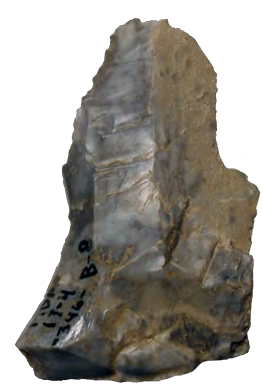

d

Fig. (7). Overshot Specimen \#6, Biface.

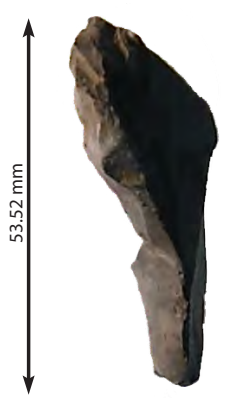

a

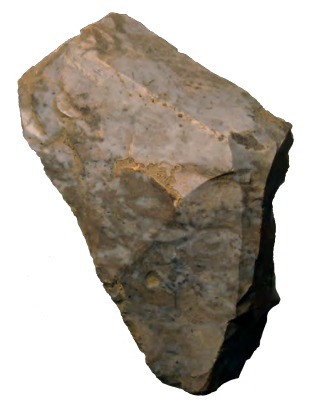

b

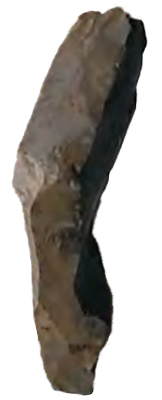

C

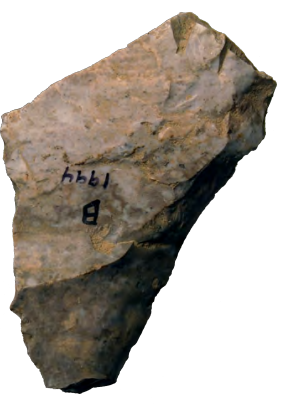

d

Fig. (8). Overshot Specimen \#7, Flake.

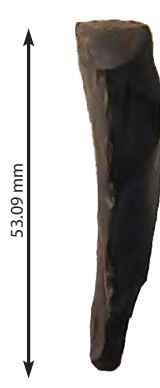

a

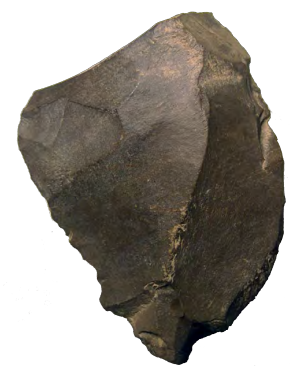

b
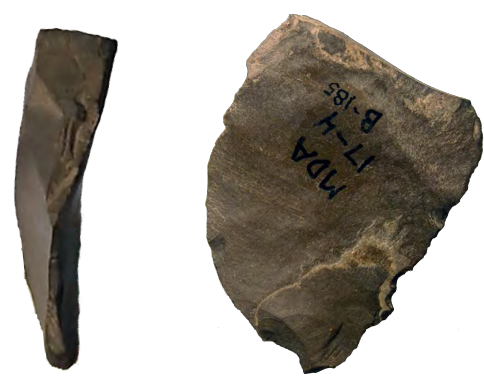

d

Fig. (9). Overshot Specimen \#8, Flake.

Full-faced flake scars are evident on the dorsal surface, which may be previous (but failed) attempts to removed the square edge, though perhaps these dorsal flake scars in- tended to establish a ridge along the axis of flaking. The platform is ground smooth, and was well isolated via two small flake removals. 

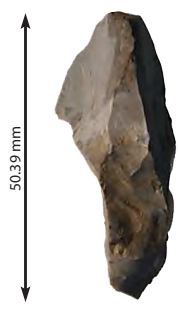

a

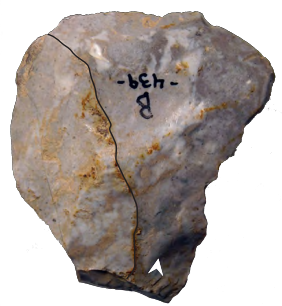

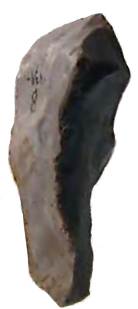

c

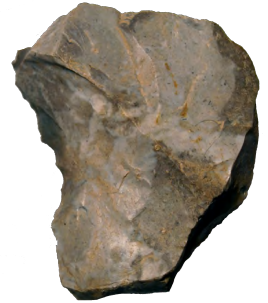

d

Fig. (10). Overshot Specimen \#9, Flake.

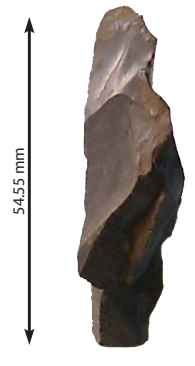

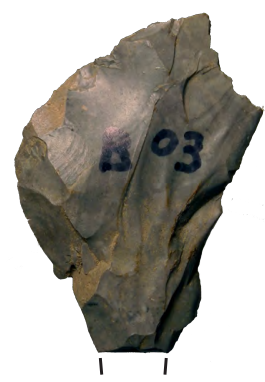

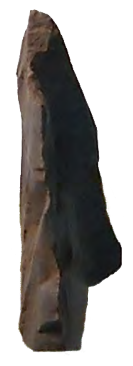

c

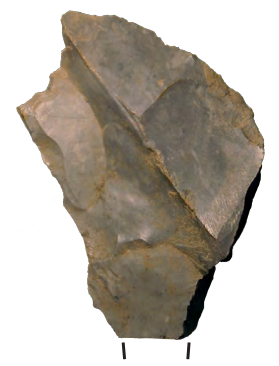

d

Fig. (11). Overshot Specimen \#10, Flake.

Overshot Specimen \#9, Flake (B-439), Fig. (10). This overshot flake removed the flat section of a tabular nodule. There is a dihedral platform and evidence of a previous overshot removal on the flake's dorsal surface.

Overshot Specimen \#10, Flake (B-03), Fig. (11). This overshot flake removed the edge of a biface. The flake was snapped, and thus the proximal section and platform is missing.
Overshot Specimen \#11, Flake (C 1992), Fig. (12). This overshot flake removed the edge of a bifacial edge that was quite thick and bulky. The flake was snapped close to the platform, which is missing.

Overshot Specimen \#12, Flake (MDA 17-4 B-433), Fig. (13). This overshot flake removed the square edge of a chert nodule. A dorsal ridge is evident along the axis of flaking, which was made more prominent via partial cresting. The

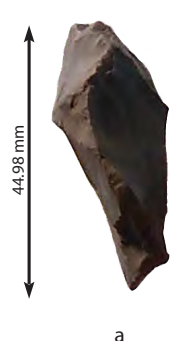

a

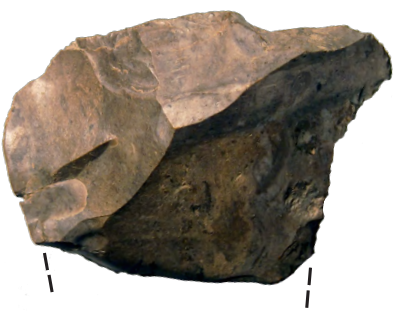

b

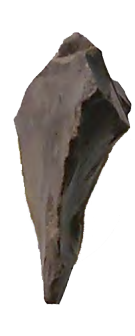

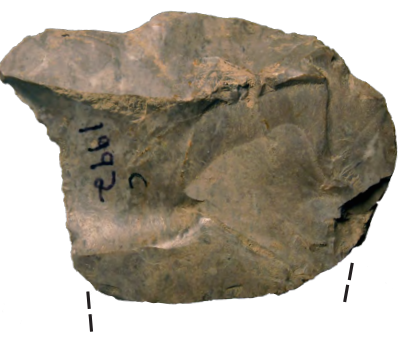

d

Fig. (12). Overshot Specimen \#11, Flake.

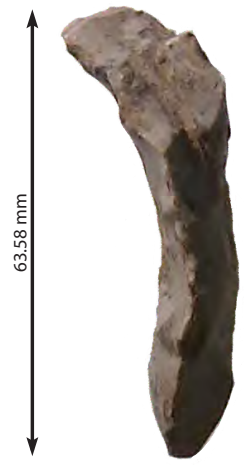

a

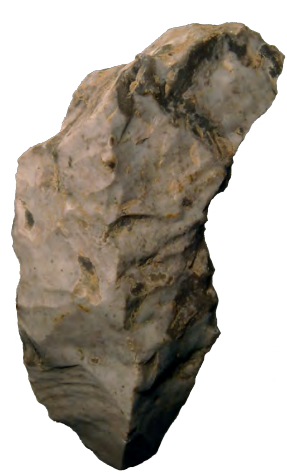

b

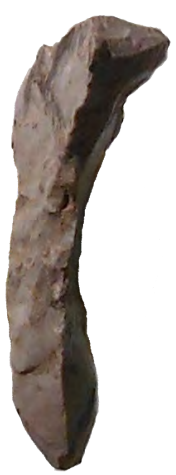

c

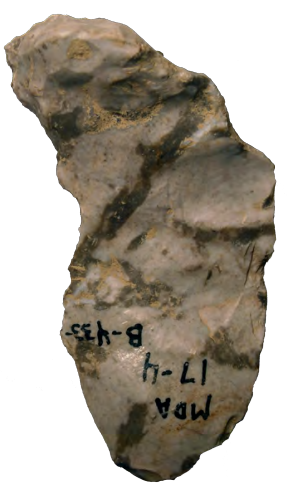

d

Fig. (13). Overshot Specimen \#12, Flake. 


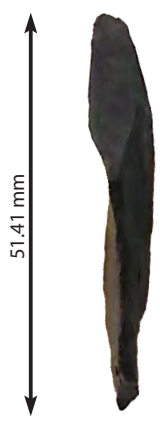

a

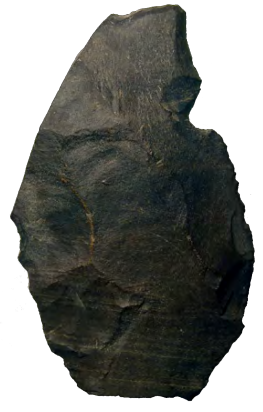

b

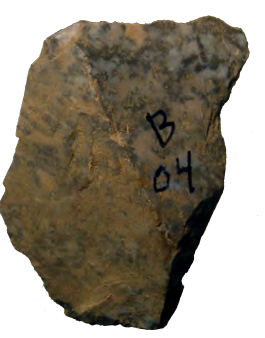

b

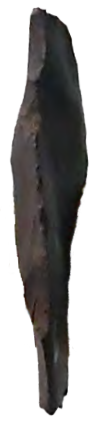

C

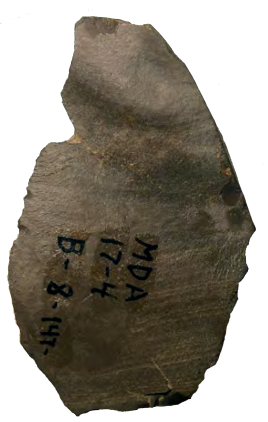

d

Fig. (14). Overshot Specimen \#13, Flake.

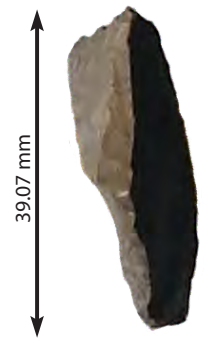

a

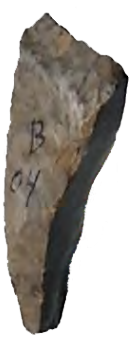

C

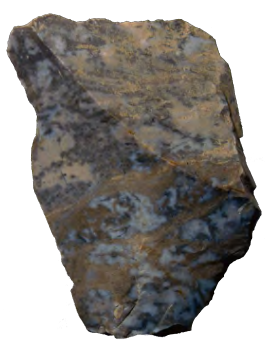

d

Fig. (15). Overshot Specimen \#14, Flake.

platform is ground smooth. There is no evidence of flake removals that isolated the platforms, but given how prominent the dorsal ridge is on the proximal section of the flake, platform isolation was perhaps unnecessary.

Overshot Specimen \#13, Flake (MDA 17-4 B-147), Fig. (14). This overshot flake removed a squared edge. The platform and proximal section of the flake are missing. A notch was retouched into the right distal edge.

Overshot Specimen \#14, Flake (B-04), Fig. (15). This overshot flake removed a flat section of a tabular nodule of chert. A prominent ridge is parallel to the axis of flaking. The battered platform is also heavily ground.

Overshot Specimen \#15, Flake scar on tabular chert nodule (1994 B), Fig. (16). A remnant overshot scar is present on a tabular chert nodule, which we speculate was originally intended to be a biface. However, bifacial reduction was

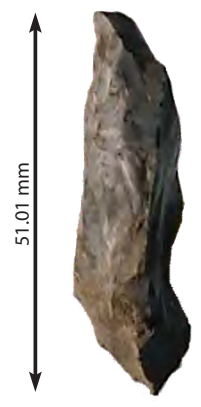

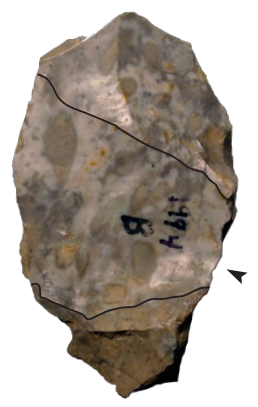

b

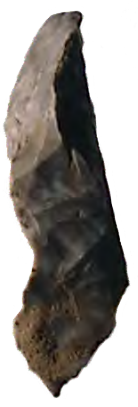

C

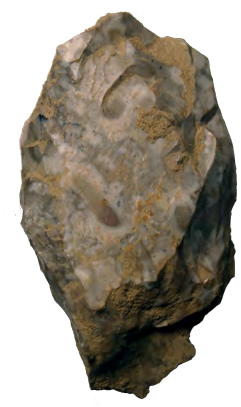

d

Fig. (16). Overshot Specimen \#15, Flake scar on tabular chert nodule. 


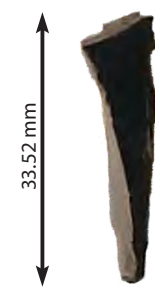

a

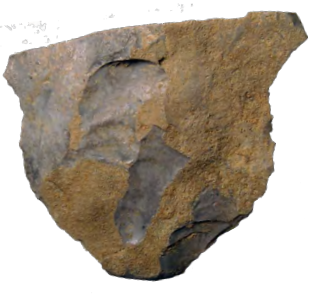

b

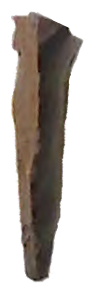

C

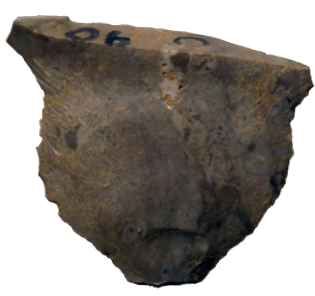

d

Fig. (17). Overshot Specimen \#16, Flake.

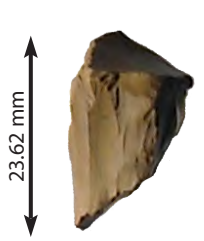

a

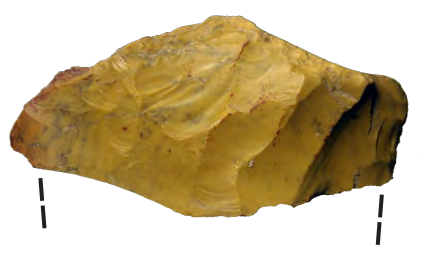

b

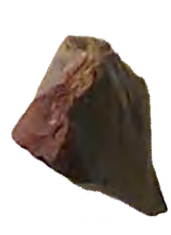

C

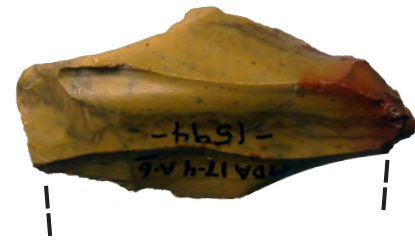

d

Fig. (18). Overshot Specimen \#17, Flake.

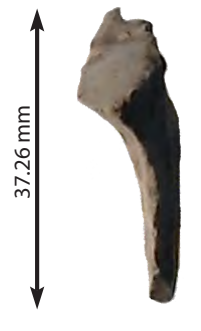

a

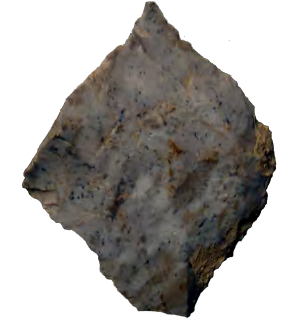

b

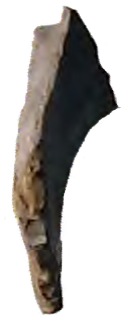

C

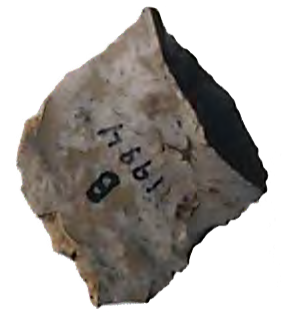

d

Fig. (19). Overshot Specimen \#18, Flake.

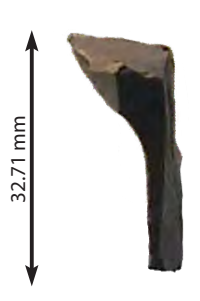

a

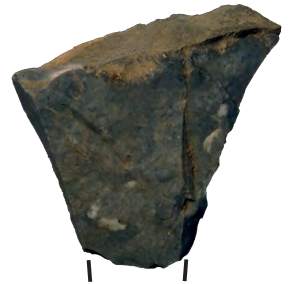

b

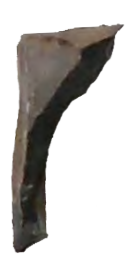

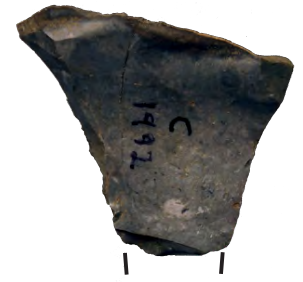

d

Fig. (20). Overshot Specimen \#19, Flake.

Overshot Specimen \#19, Flake (C 1992), Fig. (20). This overshot flake removed a square edge. Only the distal and mid-sections of the specimen are present.

Overshot Specimen \#20, Flake (C 1993), Fig. (21). This overshot flake removed a square edge. The specimen is nearly complete, through the platform is missing.

Overshot Specimen \#21, Flake (B 1994), Fig. (22). This narrow overshot flake removed a square edge. The platform is isolated, but crushed.

Overshot Specimen \#22, Flake (C 1992), Fig. (23). This overshot flake removed a bifacial edge. The left lateral edge of the overshot also removed a square edge. The proximal portion and platform are missing.

Overshot Specimen \#23, Flake (05 B), Fig. (24). This overshot flake removed a chunky bifacial edge. The proximal portion and platform are missing.

Overshot Specimen \#24, Flake (MDA 17-4 B-107), Fig. (25). This specimen is the distal portion of an overshot flake that removed a square edge. The flake shows retouch on the left lateral edge.

Overshot Specimen \#25, Flake (B 1994), Fig. (26). This overshot flake removed a square edge from a tabular nodule 


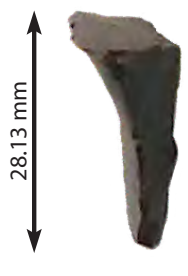

a

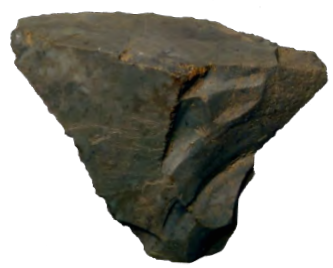

b

Fig. (21). Overshot Specimen \#20, Flake.

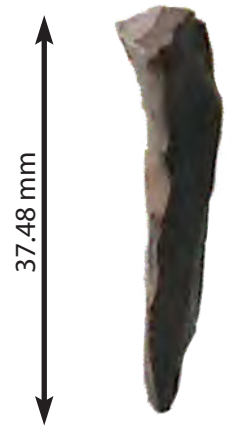

a

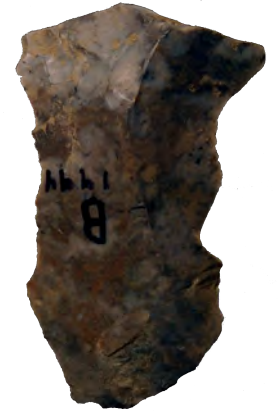

b

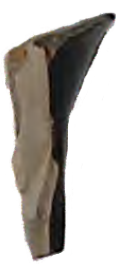

C

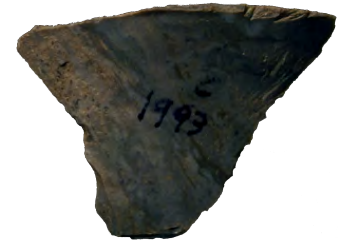

d

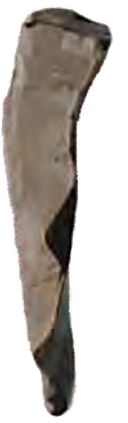

C

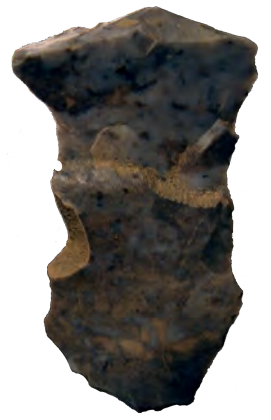

d

Fig. (22). Overshot Specimen \#21, Flake.

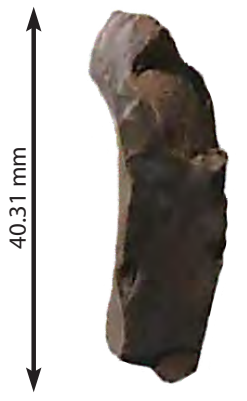

a

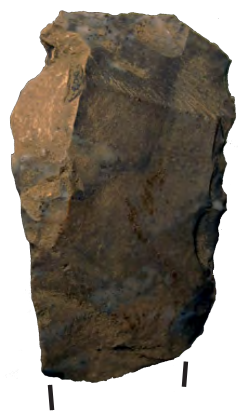

b

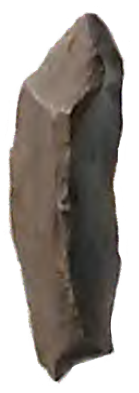

C

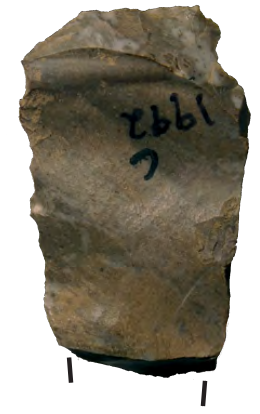

d

Fig. (23). Overshot Specimen \#22, Flake.

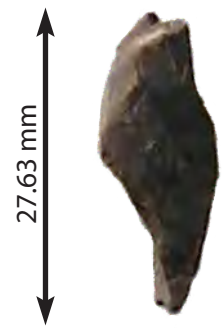

a

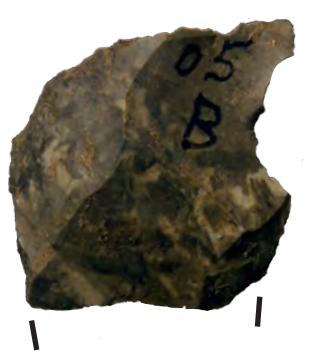

b

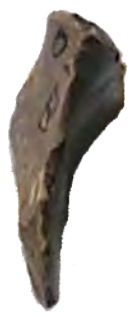

C

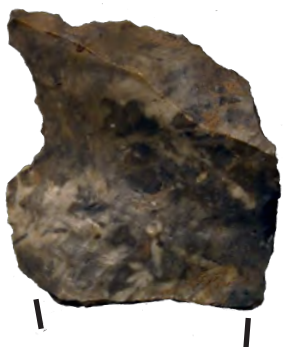

d

Fig. (24). Overshot Specimen \#23, Flake.

of chert. There are no flake scars on the dorsal portion of the overshot, indicating that it was removed early during the reduction sequence. The platform has been snapped off.

Plunging Specimen \#1, Biface (C 1992), Fig. (27). This biface shows a basal thinning flake struck from each face. However, the second flake plunged, splitting the biface in two, and cutting off the end of the first basal thinning flake scar. Two more flakes were removed after the plunging flake, but the specimen was ultimately discarded.

Plunging Specimen \#2, Biface (MDA 17-4 B-4), Fig. (28). This biface shows full-faced (long and broad) flaking on one face. The second face shows a plunging scar from a basal thinning flake. However, this scar appears as a plunging scar because the biface has snapped in two. The break 


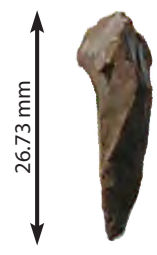

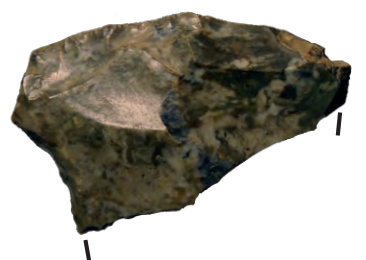

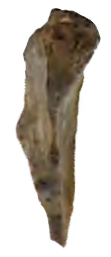

C

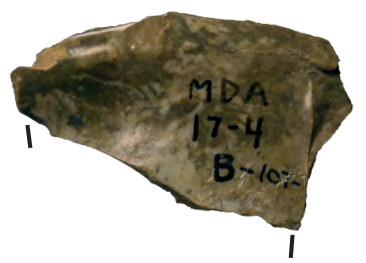

d

Fig. (25). Overshot Specimen \#24, Flake.

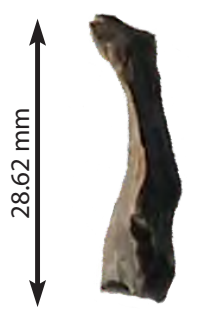

a

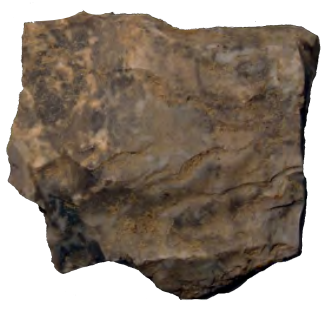

b

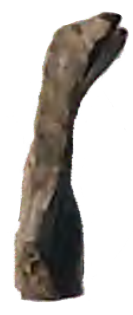

C

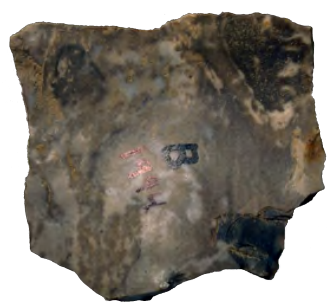

d

Fig. (26). Overshot Specimen \#25, Flake.

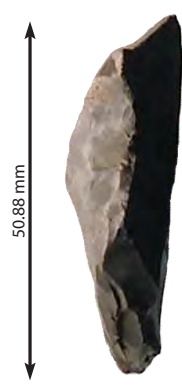

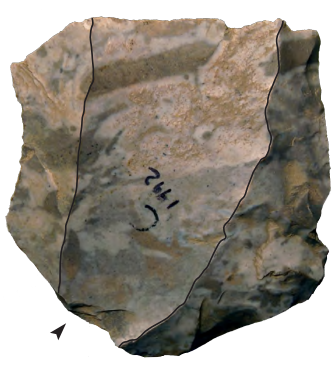

b

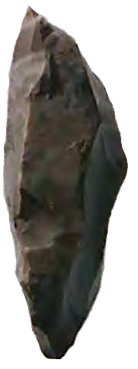

c

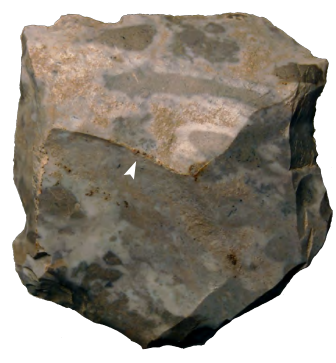

d

Fig. (27). Plunging Specimen \#1, Biface.

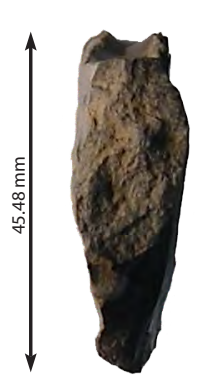

a

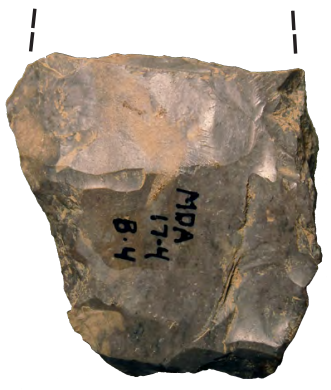

b

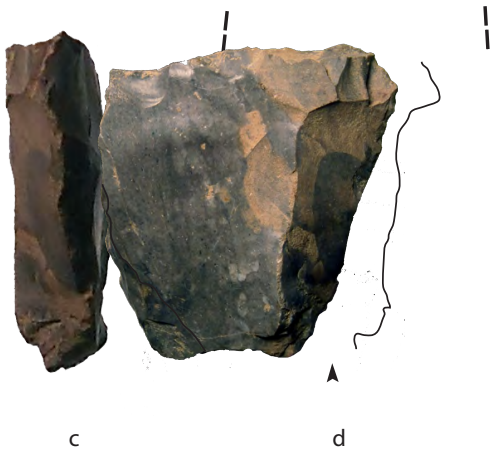

Fig. (28). Plunging Specimen \#2, Biface.

may have been caused by "end-shock" from striking the basal thinning flake, or from heat damage (there is some crystallization on the right lateral edge.

Plunging Specimen \#3, Core (MDA 17-4 B-4), Fig. (29). The specimen only has flake scars on one face, and one of these has plunged. Given the prepared platform area and patterning of other flake scars, it is clear that this specimen is a wedge-shaped blade core (see [24], Fig. 6.8). The plunging flake scar actually represents a plunging blade that removed the bottom of the core, substantially shortening any other

blade that would have been removed. Thus, the core was abandoned.

\section{SUMMARY AND DISCUSSION}

One striking aspect of overshot flaking at Arc involves the array of situations in which it was used. Both square edges and thick bifacial edges were removed using overshot flaking, and the technique was also used for bifacial thinning. The flakes that still possess their platforms show them to be ground and well-isolated. The Arc site provides a glimpse into a reduction practice that might have been com- 


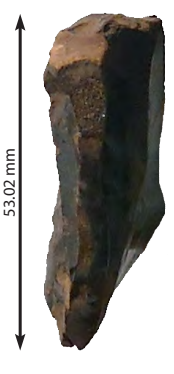

a

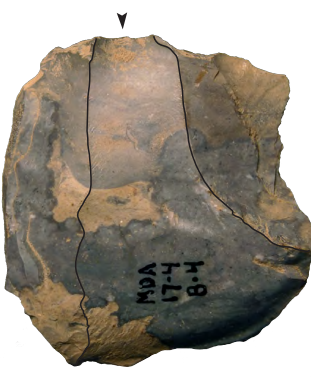

b
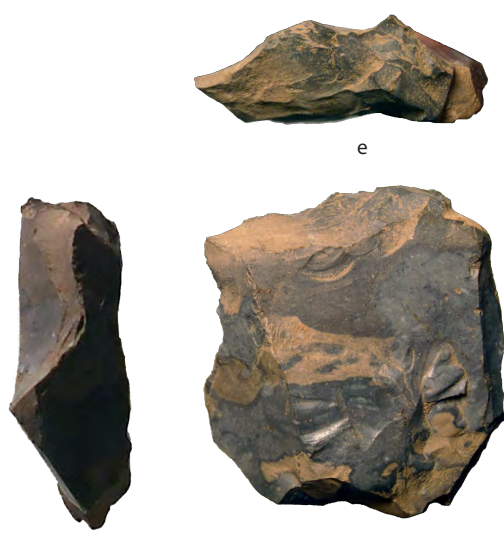

Fig. (29). Plunging Specimen \#3, Core.

mon, but is otherwise rarely seen archaeologically. All these observations accentuate the importance of Arc in Paleoindian studies around the Great Lakes, and calls attention to the need for more archaeological survey near raw material sources, as well as for more extensive and systematic analyses of the Arc site assemblage itself.

Yet, it is important to note that square-edge removal via overshot flaking is not absent from later Great Lakes $\mathrm{Pa}$ leoindian traditions either. At the Parkhill site in Ontario (ca. 10,700-10,500 B.P.), Ellis and Deller [25] illustrate that Paleoindians utilized overshot flaking to initially reduce tabular nodules of Fossil Hill chert and to produce tool blanks. While it is difficult to prove that the shape of an original chert nodule "determined" the reduction strategy, we suggest that some flintknapping strategies are simply more appropriate than others for dealing with particular raw material constraints. This idea speaks to the fact that in some cases overshot flaking may simply be a better response to the earliest stages of reduction when dealing with tabular nodules. Why, then, overshot flaking was practiced in middle and later stages of bifacial reduction at Arc remains uncertain [1].

Due to the ephemeral and exhausted Paleoindian archaeological record in the Great Lakes region, it is understandable that researchers would suggest that overshot flaking was not practiced during the manufacture of Gainey bifaces. Yet, it is important to realize, as Morrow and Morrow [9] do, that some evidence may be more appropriate for testing a hypothesis than other evidence. In this case, the early stage bifaces and debitage from the Arc site currently suggests that overshot flaking was, indeed, practiced among Paleoindians in the Great Lakes. This would indicate that certain aspects of Gainey technology are more like Clovis technology than is generally thought. Thus, while finished Paleoindian projectile point forms may have diverged due to cultural drift [3], we wonder if Paleoindian technology possesses more "cultural inertia" and thus aspects of it are more likely to last despite the fact that its end-products are evolving.

None of this negates Morrow and Morrow's [9] correct observation that finished Gainey bifaces rarely, if ever, exhibit overshots. But finished Gainey bifaces are rarely, if ever, found in an unexhausted state. This is not the case for
Clovis, which has yielded cache bifaces, and bifaces near quarries, e.g. the Gault Site. Which brings us to the purpose of the overshot: it is a thinning and shaping strategy, not a resharpening strategy. That Gainey bifacial flake scars often meet in the center of the biface (Table 1) is probably an indication of tool recycling and resharpening, as opposed to tool design. Given that Gainey sites are the earliest in the Lower Great Lakes, closely clustering around 11,000 B.P., and that Gainey toolstone procurement patterns appear to indicate a south-to-north migration into the region, there is good reason to argue that the people crafting Gainey bifaces were colonizers into this recently deglaciated landscape. As foragers attempted to find new toolstone sources in a pristine landscape, they would have had to extend tool use-life through heavy resharpening (medial flaking), in turn masking overshot flaking from earlier production stages.

All this speaks to the need for more comparisons between Clovis and Gainey technology to determine whether they are simply variations on a single theme, and thus should be both designated as "Clovis", or whether two monikers are warranted because they really are two fundamentally different technological entities. This dilemma has important research implications. If the "variations on a single theme" hypothesis is adopted, then the geographic range of Clovis technology is expanded into the North American Lower Great Lakes region and Ontario (see 1, Fig. 8.1), adding yet another region to which Clovis successfully inhabited. Any regional morphological differences would be due to adaptive contexts (e.g., non-colonizing Clovis in the western USA vs. colonizing Clovis in the Lower Great Lakes). If the "dualdesignation" hypothesis is pursued, researchers need to explain the sudden emergence of the new Gainey technological entity in the Lower Great Lakes. Both hypotheses will require empirical and quantified patterns on entire assemblages (not just bifaces) from a large sample of Clovis and Gainey sites to demonstrate whether intrinsic technological (not morphological) differences are present.

While there are important links between technology, mobility, and toolstone exhaustion, it is how these links are read by researchers that ultimately shapes the cultural sequences of Paleoindian archaeology. The presence of Paleoindian overshot flaking at the Arc site reveals the similarity of two allegedly distinct technologies, in turn suggesting that any 
morphological or technological dissimilarities may be attributed to the extent and nature of projectile point resharpening. It appears that we may not understand Gainey technology and its relation to Clovis production as well as we have assumed. We suggest that a technological, and perhaps a terminological [26, 27], reexamination of the "Gainey concept" is in order. Future analyses of the immense Arc site assemblage by other researchers will certainly play an important role.

\section{ACKNOWLEDGEMENTS}

M.I.E. is financially supported by a National Science Foundation (NSF) Graduate Research Fellowship, and by Mustafa, Kathleen, and Nimet Eren. Thanks to Tony Baker, Bruce Bradley, Rebecca Catto, R. Michael Gramly, David Meltzer, Robert Patten, Brian Redmond, C. Garth Sampson, and two anonymous reviewers for comments on early drafts of this manuscript.

\section{REFERENCES}

[1] Bradley B, Collins M, Hemmings C. Clovis technology. archaeological series, international monographs in prehistory. Ann Arbor 2010; p. 68.

[2] Meltzer D. What do you do when no one's been there before? Thoughts on the exploration and colonization of new lands. In: Jablonski N, Ed. The First Americans: The Pleistocene Colonization of the New World. California Acad Sci 2002, pp. 27-58.

[3] Buchanan B, Hamilton J. A formal test of the origin of variation in North American early Paleoindian projectile-points. Am Antiquity 2009; 74(2): 279-98.

[4] Morrow J, Morrow T. Geographic variation in fluted projectile points: a hemispheric perspective. Am Antiquity 1999; 62(4): 21531.

[5] Brose D. Archaeological investigations at the Paleo Crossing Site, a Paleoindian occupation in Medina County, Ohio. In: Dancey W, Ed. The First Discovery of America: Archaeological Evidence of the Early Inhabitants of the Ohio Area, The Ohio Archaeological Council, Inc., Columbus 1994; pp. 61-76.

[6] Ellis C, Deller D. An Early Paleo-Indian Site Near Parkhill, Ontario. Canadian Museum of Natural History, Hull: Mercury Series Archaeol Survey of Canada Paper 159, 2000.

[7] Eren M. Paleoindian stability during the younger dryas in the north american lower great lakes. In: Shea J, Lieberman D, Eds. Transitions in Prehistory: Papers in Honor of Ofer Bar-Yosef, American School of Prehistoric Research Press and Oxbow Books 2009; pp. 389-422.

[8] Seeman M. Intercluster lithic patterning at Nobles Pond: a case for "disembedded" procurement among early Paleoindian societies. Am Antiquity 1994; 59(2): 273-88.

[9] Morrow J, Morrow T. Exploring the Clovis-Gainey-Folsom continuum: technological and morphological variation in midwestern fluted points. In: Clark J, Collins M, Eds. Folsom Technology and Lifeways, Lithic Technology Special Publication No. 4 1999, pp. 141-157.

[10] Haynes G. The Early Settlement of North America: The Clovis Era. Cambridge: Cambridge University Press 2002; p. 83.

[11] Bradley J, Spiess A, Boisvert R, Boudreau J. What's the point? modal forms and attributes of Paleoindian bifaces in the New England-Maritimes region. Archaeol East North Am 2008; 36: 119-72.

[12] Gramly, R. Evidence of Clovis in Northeastern North America [online]. 2006, [cited 2010]. Available from: http//www.lithiccastinglab.com/gallery-

pages/2006juneclovisinnortheastpage1.htm

[13] Prufer O, Baby R. Paleoindians of Ohio. Columbus: The Ohio Historical Society 1975.

[14] Tankersley K. Variation in the early Paleoindian economies of Late Pleistocene Eastern North America. Am Antiquity 1998; 63(1): 720.

[15] Callahan E. The basics of biface knapping in the eastern fluted point tradition: a manual for flintknappers and lithic analysts. Archaeol East North Am 1979; 7: 1-180.

[16] Barrish B. The Paleo Crossing Site: Fluted Point Typology and Chronology. M.A. Thesis. Kent (OH): Kent State University 1995; p. 71.

[17] Ennis R, Hess M, Holland J, et al. Survey and test excavations at the Arc site, Genesse County, New York. Curr Res Pleistocene 1995; 12: 9-11

[18] Gramly R, Vanderlaan S. A Chert Sickle from the Arc Paleoindian Site, Western New York. Curr Res Pleistocene 1986; 3: pp. 29-31.

[19] Tankersley K, Vanderlaan S, Holland J, Bland S. Geochronology of the Arc site: a Paleoindian habitation in the Great Lakes region. Archaeol East North Am 1997; 25: 31-44.

[20] Vanderlaan S. The Arc site. The Iroquoian 1986; 12: 64-73.

[21] Tankersley K. General stratigraphy and geochronology of the Arc site, Genesse County, New York. Current Research in the Pleistocene 1996; 13: 125-7.

[22] Binford L. In: Pursuit of the Past: Decoding the Archaeological Record. Berkeley: University of California Press 1983.

[23] Frison G, Bradley B. The Fenn Cache: Clovis Weapons and Tools Santa Fe: One Horse Land and Cattle Company 1999; p. 10.

[24] Collins M, Lohse J. The Nature of Clovis Blades and Blade Cores. In: Madsen D, Ed. Entering America: Northeast Asia and Beringia Before the Last Glacial Maximum, University of Utah Press, Salt Lake 2004; pp. 159-183.

[25] Ellis C, Deller D. Variability in the archaeological record of northeastern early Paleoindians: a view from southern Ontario. Archaeol East North Am 1997; 25: 1-30.

[26] Bar-Yosef, O. Between observations and models: an eclectic view of Middle Paleolithic archaeology. In: Hovers E, Kuhn S, Eds. Transitions Before the Transition: Evolution and Stability in the Middle Paleolithic and Middle Stone Age Springer, New York 2006; pp. 305-325.

[27] Gramly R, Funk R. What is known and not known about the human occupation of the Northeastern United States until 10,000 B.P. Archaeol East North Am 1990; 18: 5-31

(C) Eren et al.; Licensee Bentham Open.

This is an open access article licensed under the terms of the Creative Commons Attribution Non-Commercial License (http://creativecommons.org/licenses/by-nc/3.0/) which permits unrestricted, non-commercial use, distribution and reproduction in any medium, provided the work is properly cited. 